\title{
Extraction and isolation of anti-tryptic castor-bean (Ricinus communis L.) substances and their effects on Spodoptera frugiperda (Smith, 1797) (Lepidoptera: Noctuidae)
}

\author{
Vinicius Ramos $^{1 *}$, Dejane Alves ${ }^{1}$, Mariana Braga $^{1}$, Geraldo Carvalho $^{1}$, and Custódio Santos ${ }^{1}$
}

The search for alternative methods aiming to the control of agricultural pests that cause less environmental impact has been a recurring theme in several studies. For this purpose, the factors influencing the extraction and isolation of the trypsin inhibitor found in castor-bean (Ricinus communis L.) cake and seeds were studied, and its effect on the development of fall armyworm Spodoptera frugiperda (Smith, 1797) was evaluated. Therefore, the type and proportion of the solvent (w/v), extraction period and oil content were evaluated. The castor-bean cake extract with oil content of $20 \%$ in water at a ratio 1:40 (w/v) for 30 min showed the greatest trypsin inhibition, with $21.23 \mathrm{mUTI} \mathrm{g}^{-1}$ seed. The isolation of the trypsin inhibitor contained in the extract was performed by flash chromatography, with inhibition peaks of up to $8906.12 \mathrm{mUTI}^{-1}$ fraction, as well as inferring that the best eluent was ethyl acetate with a small percentage of ethanol $(<30 \%)$. In order to evaluate the effect of the inhibitor on the development of this insect, the aqueous extract of castor bean cake with oil content of $20 \%$ was incorporated into the diet that was provided to the caterpillars at a concentration of $4000 \mathrm{ppm}$. There was reduction in the oviposition period and an increase in the concentration of proteins in the feces, with $20.55 \pm 3.73 \mathrm{~d}$ and $177.70 \pm 16.90$ $\mu \mathrm{mol} \mathrm{\textrm {g } ^ { - 1 }}$, respectively. The increase in protein excretion indicates that the trypsin inhibitor was able to reduce the absorption of essential amino acid residues by the insect without, however, impairing the development of S.frugiperda.

Key words: Zea mays, fall armyworm, Ricinus communis, trypsin inhibitor, alternative control.

\section{INTRODUCTION}

The use of plant extracts aiming the control of fall armyworm (Spodoptera frugiperda Smith, 1797) is considered promising, since the plants defend themselves from the attack by insects and other organisms through several mechanisms, among which stand out the synthesis and accumulation of toxic proteins, e.g. trypsin inhibitors. Since the discovery of protease inhibitors as a plant defense mechanism, numerous attempts have been made for its use in plant breeding (Mosolov and Valueva, 2008).

When insects cause injury to a specific part of the plant this can induce production of endopeptidase inhibitors in various parts of the plant, which usually act on the digestive system of insects. This plant internal communication mechanism is activated by the systemin, a phytohormone that acts on genes producers of protease inhibitors (Lopes et al., 2004).

Protease inhibitors are produced by several species of plants and act on the regulation of proteolysis, amino acid stock and defense against pathogens and pests. Inhibitors of serine proteases are of greater abundance and variety in nature, being divided into eight families: Kunitz inhibitor, Bowman-Birk type inhibitors, inhibitors of potato families

${ }^{1}$ Federal University of Lavras, Chemistry Department, PO box 3037, CEP 37200-000 Lavras, Brazil.

*Corresponding author (viniciusoramos@yahoo.com.br).

Received: 7 December 2012

Accepted: 19 March 2013.

doi:10.4067/S0718-58392013000200007.
I and II, trypsin inhibitors found in pumpkins, trypsin and $\alpha$-amylase inhibitors from cereal, trypsin inhibitors found in mustard, and the inhibitors from the family of the Serpins, while there is only one family of inhibitors of cysteine proteases, which are phytocystatins (Mosolov and Valueva, 2005).

The most pronounced effect of these inhibitors occurs when forming a stable complex with digestive enzymes, limiting amino acid hydrolysis and making it extremely slow (Jongsma and Beekwilder, 2011). This mechanism interferes on the development, due to the deficiency of essential amino acid residues available. The use of protease inhibitors as a means of control of $S$. frugiperda was evaluated by Paulillo et al. (2000), and it was discovered that the insect adapts to Kunitz and BowmanBirk inhibitors. Brioschi et al. (2007) reported that the mechanism of resistance of the fall armyworm occurs through the expression of several isoenzymes, some of them immune to these inhibitors.

Trypsin inhibitors described in the literature are typically protein, unlike the inhibitor found in castorbean leaves, a polar and non-proteic molecule, whose molecular structure remains unknown. The mechanisms of inhibition for some protease inhibitors have been described. However, it is still not known for sure how a non-protein inhibitor influences the enzymatic hydrolysis. Understanding how this mechanism works can contribute to new research that aim to use this substance in the control of pests of economic importance (Benchabane et al., 2010; Rossi et al., 2010). 
Due to the damage caused by S. frugiperda to corn (Zea mays L.) and its tolerance to a wide range of insecticides, the search for new control methods, especially those that cause less environmental impact, can be justified, since the application of insecticides usually causes biological imbalances, intoxication of applicators and environmental contamination. In this context, the aims of this study were to evaluate techniques for extraction and isolation of trypsin inhibitors in castor-bean (Ricinus communis L.) seeds and cake, and the effect of these inhibitors on the development of S. frugiperda.

\section{MATERIALS AND METHODS}

The experiments were carried out in the Biochemistry (Chemistry Department) and in the Integrated Pest Management (Entomology Department) laboratories, at Federal University of Lavras (UFLA), Brazil. The castorbean seeds, cv. Guarani moisture content $3.34 \%$, were provided by the technicians from the Seed Laboratory at UFLA.

\section{Preparation of the castor-bean seeds and cake extracts}

Seeds were ground, so that they could be degreased with ethyl ether in a system for fat determination (model TE-044-8/50, Tecnal, Piracicaba, São Paulo, Brazil) for different periods of time, aiming to obtain castor-bean cakes (solid waste) with different oil contents, in order to make it possible to evaluate their interference in the extraction of the trypsin inhibitor.

The first extraction process was carried out with castor-bean cake with $0 \%$ oil content, and the extracts were obtained according to the methodology proposed by Carvalho (2009). The castor-bean cake static percolation was performed in a solvent for $7 \mathrm{~d}$ at a ratio of 1:20 (w/v) using ethyl acetate, and after this period the extract was filtered and named Ac0\%. The remainder castor-bean cake of this first extraction was subjected to the same process, but using ethanol, and the obtained extract was named ET0 This process was also carried out with methanol, thereby obtaining the extract $\mathrm{Me} 0 \%$. The extracts obtained had their solvent removed in a rotoevaporator (Model 208, Fisatom, São Paulo, Brazil) at 20 ${ }^{\circ} \mathrm{C}$ below the boiling point of the solvents used and the solid residue was dissolved in water for later analysis of the trypsin inhibition of $S$. frugiperda.

The second procedure involved agitation of ground seeds in presence of ethanol and water. The ethanolic extract of seeds $\left(\mathrm{Et}_{\text {seed }}\right)$ was obtained by orbital shaking for $60 \mathrm{~min}$ at a ratio of 1:80 (w/v); this mixture was centrifuged and the supernatant was filtered, and then concentrated on a roto-evaporator. The residue obtained was dissolved in ethyl ether at a ratio of 1:80 (w/v). In a dropping funnel, a liquid/liquid partition was performed and the ether was washed with distilled water, using double the amount of water used in the dissolution; the ethereal fraction was discarded. The aqueous fraction was concentrated on the roto-evaporator and the solid residue was dissolved in $10 \mathrm{~mL}$ ethanol for use in in vitro trypsin inhibition tests. The seed aqueous extract $\left(\mathrm{Aq}_{\mathrm{seed}}\right)$ was obtained by 60 min agitation of ground seeds with water at a ratio of 1:40 $(\mathrm{w} / \mathrm{v})$; the mixture was then centrifuged and the supernatant was filtered to be used in the in vitro inhibition tests.

The aqueous extracts of cake with oil contents of 20, 26, 30, 34, 41, 45, and 48\% (extracts Aq20\%, $\mathrm{Aq} 26 \%, \mathrm{Aq} 30 \%, \mathrm{Aq} 34 \%, \mathrm{Aq} 41 \%, \mathrm{Aq} 45 \%$, and $\mathrm{Aq} 48 \%$, respectively) were obtained the same way as the $\mathrm{Aq}_{\text {seed }}$ was, and their inhibitory potential was evaluated in in vitro S. frugiperda trypsin inhibition assays, aiming to determine the oil effect on the anti-tryptic activity.

The extract Aq20\% suffered optimization during agitation period and in the proportion of solvent; four periods of time were tested $(30,60,90$, and $120 \mathrm{~min})$ and four ratios $(1: 10,1: 20,1: 30,1: 40,1: 50$, and 1:75 w/v) in order to obtain a greater amount of inhibitor for use in biological assays and chromatographic fractionation. For this reason, the extract was oven dried at $45^{\circ} \mathrm{C}$ and in vitro trypsin inhibitory activity of solid residue was evaluated after dissolution of $2.5 \mathrm{mg} \mathrm{mL}^{-1}$ distilled water. The choice of Aq20\% extract was based on the reliability of the absorbance readings during enzyme kinetic assay of trypsin inhibition experiments, in addition to making it possible to calculate mass/volume concentration in preparation of the diet provided to the caterpillar, and in the chromatographic fractionation.

\section{Enzyme kinetic assay of trypsin inhibition}

Sixth instar of $S$. frugiperda caterpillars from laboratory rearing, were immobilized at $-20^{\circ} \mathrm{C}$ for $10 \mathrm{~min}$ and their digestive tubes were removed with the aid of forceps and scissors, and then macerated in Potter homogenizer at a ratio of one digestive tract to $4 \mathrm{~mL}$ of distilled water at $4{ }^{\circ} \mathrm{C}$. The crude extract was then filtered on a $100 \mu \mathrm{m}$ nylon mesh and centrifuged at $10000 \mathrm{~g}$ at $4{ }^{\circ} \mathrm{C}$ for 30 $\mathrm{min}$. The supernatant, considered the enzyme extract, was then stored in a freezer at $-20{ }^{\circ} \mathrm{C}$ until its use (Rossi et al., 2010).

The substrate used in the trypsin inhibition assays was the N- $\alpha$-benzoyl-DL-arginine-4-nitroanilide hydrochloride (BAPNA) at $1.25 \mathrm{mmol} \mathrm{L}^{-1}$ and in a $0.1 \mathrm{M}$ glycine-sodium hydroxide (Gly-NaOH) buffer ( $\mathrm{pH} 9.7)$. To prepare the solution, $54.5 \mathrm{mg}$ BAPNA were solubilized in $1.25 \mathrm{~mL}$ of dimethyl sulfoxide (DMSO) and then added up to $100 \mathrm{~mL}$ with Gly-NaOH buffer.

The assay was kinetically performed, with four periods of reaction time: 30, 60, 90, and $120 \mathrm{~min}$. For each inhibition assay, $200 \mu \mathrm{L}$ extract containing inhibitor, 200 $\mu \mathrm{L}$ suitably diluted enzyme (enzyme extract) and $800 \mu \mathrm{L}$ substrate solution were added to the reaction mixture, thus initiating the reaction. The control test was performed without inhibitor to occur at full speed. The reaction was 
stopped with $200 \mu \mathrm{L} \mathrm{30 \%} \mathrm{acetic} \mathrm{acid} \mathrm{and} \mathrm{absorbance} \mathrm{was}$ read at $410 \mathrm{~nm}$, according to the methodology proposed by Erlanger et al. (1961).

It is noted that 1 UTI (unit of trypsin inhibited) corresponds to $1 \mu \mathrm{mol}$ of p-nitroanilide, which ceases to be produced due to the presence of the inhibitor; whereas the results in this study were expressed in mUTI g $^{-1}$ seed in the extraction procedures and in $\mathrm{mUTI} \mathrm{g}^{-1}$ fraction and $200 \mu \mathrm{L}$ in the chromatographic purification procedures.

\section{Fractionation of Aq20\% extract by adsorption flash chromatography}

A glass column $(3 \mathrm{~cm}$ diameter $\times 50 \mathrm{~cm})$ was filled with silica gel 60 Merck mixed with chloroform; $113.80 \mathrm{~g}$ silica were suspended in chloroform for the mixture became fluid. This fluid was poured into the column forming the stationary phase (Rossi et al., 2010).

As the detection method used was based on a kinetic assay of trypsin inhibition, which does not allow realtime detection, three chromatographies were required to determine the best concentration and better eluents. The Aq20\% extract was diluted in distilled water and subjected to fractionation in concentrations of $0.06,0.01$, and $0.5 \mathrm{~g} \mathrm{~mL}^{-1}$ distilled water, and $1 \mathrm{~mL}$ of these dilutions was injected.

The fractions were collected in $100 \mathrm{~mL}$ containers, concentrated on a roto-evaporator and transferred to 15 $\mathrm{mL}$ vials. The remaining solvent was evaporated in an oven at $45^{\circ} \mathrm{C}$. The residue was dissolved in $2 \mathrm{~mL}$ distilled water in an orbital shaker for $1 \mathrm{~h}$. Detection was carried out by an inhibition enzymatic assay in all the fractions obtained from the three chromatographies performed.

The first two chromatographies showed the peak of trypsin inhibition in the ethyl acetate/ethanol interphase, even with different sample concentrations and eluent volumes, which indicates that the best elution range was a mixture of ethyl acetate/ethanol. In the third chromatography, a run was performed with the sample in the concentration of $0.5 \mathrm{~g} \mathrm{~mL}^{-1}$ and it was eluted with the following eluotropic series: ethyl acetate; ethyl acetate solution/ethanol in a 70:30 ratio; ethyl acetate solution/ ethanol in a 30:70 ratio, and pure ethanol.

\section{Effects of addition of Aq20\% extract on the diet at different developmental stages of $S$. frugiperda}

Second instar of $S$. frugiperda caterpillars from laboratory rearing, were transferred to glass tubes $(3 \mathrm{~cm}$ diameter $x$ $10 \mathrm{~cm}$ ) in the proportion of one caterpillar per container, containing the diet prepared according to the methodology proposed by Kasten Jr. et al. (1978). The bioassay consisted of a control treatment containing distilled water and a treatment containing aqueous extract of castorbean cake at $4 \mathrm{~g} \mathrm{~L}^{-1}$. This value was used as a result to be among the concentrations of $1.6 \mathrm{~g} \mathrm{~L}^{-1}$ and $9.6 \mathrm{~g} \mathrm{~L}^{-1}$ of the methanol extract of seeds used by Ramos-López et al. (2010). The concentration of $1.6 \mathrm{~g} \mathrm{~L}^{-1}$ methanol extract was able to alter the development of the fall armyworm and at $9.6 \mathrm{~g} \mathrm{~L}^{-1}$ all caterpillars died.

In the control treatment, $270 \mathrm{~mL}$ of diet were added to $30 \mathrm{~mL}$ distilled water and, in the treatment with Aq20\% extract, $30 \mathrm{~mL}$ extract were added, whose final concentration in the diet was $4 \mathrm{~g} \mathrm{~L}^{-1}$.

In order to evaluate if the inhibitor altered the amino acid uptake by the insect, protein concentration in the feces of $S$. frugiperda caterpillar was determined, based on the methodology developed by Bradford (1976). After the end of the larval period, $45 \mathrm{mg}$ feces were collected, $200 \mu \mathrm{L}$ distilled water and $200 \mu \mathrm{L} 1 \mathrm{M}$ perchloric acid were added to the feces, and this mixture was homogenized and placed in an ice bath for $10 \mathrm{~min}$. Samples were centrifuged and supernatant was discarded, the precipitate was resuspended in $200 \mu \mathrm{L} 0.1 \mathrm{M} \mathrm{NaOH}$ and its protein concentration was determined spectrophotometrically at $594 \mathrm{~nm}$, taking as a basis a standard curve of BSA (bovine serum albumin), with protein masses ranging from 2 to $20 \mu \mathrm{g}$.

The design used in the experiment was completely randomized, with two treatments and 72 replicates, each one consisting of one $S$. frugiperda second instar caterpillar. The duration of larval and pupal period, pupal weight, protein concentration in feces, female and male longevity, pre-oviposition period, oviposition period, and number of eggs produced per couple were evaluated.

\section{Statistical analysis}

All data obtained were subjected to ANOVA. Data from solvent for extraction of trypsin inhibitor found in castorbeans, duration of larval and pupal period, pupal weight, protein concentration in feces, female and male longevity, pre-oviposition period, oviposition period, and number of eggs per couple had their averages compared by the ScottKnott test at 5\% significance level. Those data associated with proportion of water, extraction time, and oil content in the extraction of trypsin inhibitor found in castor-beans were analyzed through regression. All statistical analyzes were performed using the software R (R Core Team, 2012).

\section{RESULTS AND DISCUSSION}

\section{Extraction and evaluation of the extractant, time, proportion and oil content on the trypsin inhibitor of castor-bean seeds}

Extracts Aq20\% and $\mathrm{Et}_{\text {seed }}$ caused trypsin inhibition of $S$. frugiperd $a$ and the highest average (65.76\%) was observed in extract $\mathrm{Et}_{\text {seed }}$ treatment (Table 1). When it comes to enzyme assays, the range of acceptable percentage for calculating UTI should vary between 80 and $40 \%$. Values above these range may be masked, that is, the inhibition is greater than that observed, and smaller values may be due to dilution of the inhibitor in the extraction and, therefore, only extracts $\mathrm{Aq} 20 \%$ and $\mathrm{Et}_{\text {seed }}$ allowed calculating mUTI.

The extracts $\mathrm{Ac0} \%$, Et0\%, and $\mathrm{Me} 0 \%$ did not show trypsin inhibition, and it was not possible to evaluate 
Table 1. Comparison of trypsin inhibition (\%) and milliunits of trypsin inhibited (mUTI) caused by different extracts, obtained from castorbean seeds and cake.

\begin{tabular}{|c|c|c|}
\hline Extracts & \multicolumn{2}{|c|}{ Inhibition of trypsin } \\
\hline & $\%$ & mUTI g $^{-1}$ seeds \\
\hline Ac0\%: ethyl acetate extract from castor-bean cake $0 \%$ oil & $10.53 \pm 2.40 \mathrm{a}$ & - \\
\hline Et0\%: ethanol extract from castor-bean cake $0 \%$ oil & $6.31 \pm 0.90 \mathrm{a}$ & - \\
\hline $\mathrm{Me} 0 \%$ : methanol extract from castor-bean cake $0 \%$ oil & $8.77 \pm 0.88 \mathrm{a}$ & - \\
\hline Aq $20 \%$ : aqueous extract from castor-bean cake $20 \%$ oil & $40.44 \pm 3.94 b$ & $21.23 \pm 2.07 \mathrm{a}$ \\
\hline $\mathrm{Aq}_{\text {seed: }}$ aqueous extract from ground castor-bean seeds & - & - \\
\hline \multirow[t]{2}{*}{$\mathrm{Et}_{\text {seed }}$ : ethanol extract from ground castor-bean seeds } & $65.76 \pm 6.97 \mathrm{c}$ & $6.90 \pm 0.73 b$ \\
\hline & $\mathrm{F}=61.63 ; \mathrm{p}<0.001$ & $\mathrm{~F}=27.63 ; \mathrm{p}<0.01$ \\
\hline
\end{tabular}

Means followed by the same letter in each column are not statistically different according to Scott-Knott test at $5 \%$ significance level.

whether $\mathrm{Aq}_{\mathrm{seed}}$ extract caused inhibition or not, because the reaction mixture became turbid, due to the presence of oil, which made the reading in spectrophotometer impossible. Most trypsin inhibitors described in literature are protein and therefore their extraction is performed through saline or buffer solutions due to their effectiveness to solubilize proteins. Purification of these protein inhibitors is similarly affected by techniques as centrifugation, ammonium sulfate precipitation, acetone precipitation at $-20{ }^{\circ} \mathrm{C}$, and affinity chromatography, which are the most common for purification of proteins (Benjakul et al., 2000; Tsybina et al., 2001; Carlini and Grossi-de-Sá, 2002; Brioschi et al., 2007; Zhou et al., 2008). However, trypsin inhibitory activity present in extracts of castorbean leaves is concentrated in polar solvents and does not change at high temperatures or protein denaturing agents (Rossi et al., 2010).

When identifying compounds, extraction by solvents with increasing polarity is common, aiming grouping substances with similar characteristics, in order to facilitate their further characterization. Therefore, in the present work, this extraction technique was initially used in castor-bean cake with $0 \%$ oil. Carvalho (2009) obtained the trypsin inhibitor of castor-bean leaves using this methodology; however, in the present work, this technique was not effective for the extraction of the inhibitor in castor-bean cake with $0 \%$ oil (Table 1), probably due to the removal process of the oil present in castor-bean seeds. The presence of trypsin inhibitor in the castor-bean seed and cake was confirmed in extracts $\mathrm{Aq} 20 \%$ and $\mathrm{Et}_{\text {seed }}$, whose oil was removed by partition with ethyl ether.

For the proportions evaluated, only the ratios 1:10, $1: 20,1: 30$, and 1:40 (w/v) caused significant inhibition, and a linear increase for the trypsin inhibition in $S$. frugiperda was observed (Figure 1). Ratio 1:50 and 1:75 do not exhibit acceptable percentage to calculate inhibition. When subjected to different extraction conditions, trypsin inhibitory activity of castor-bean cake with $20 \%$ oil showed a positive correlation with the increase in water proportion in the extraction of up to $1: 40(\mathrm{w} / \mathrm{v})$. The increase in the trypsin inhibition can be explained by the greater availability of water during the extraction since, in higher proportions, the dilution effect was predominant and it did not cause significant trypsin inhibition. Moreover, referring to the extraction time of the inhibitor, there was no increase or decrease in the trypsin inhibition caused by the aqueous extract of the castor-bean cake with $20 \%$ oil, as shown in Figure 2.

Oil content in castor-bean cake caused an increase in the inhibition, which was proportional to its own increase (Figure 3). The oil content in castor-bean cake influenced the extraction of the trypsin inhibitor and, the higher the content, the greater the trypsin inhibitory activity. All extracts used in this experiment were aqueous; therefore the oil was not responsible for inhibition due to its insolubility in water. Thus, the linear relationship between oil content/trypsin inhibition can be explained by

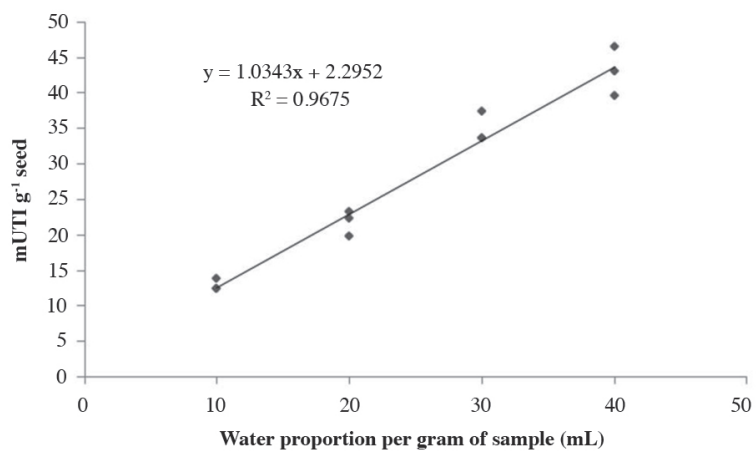

Figure 1. Curve of the effect of the water proportion on the extraction of the inhibitor present in the castor-bean cake on the inhibitory activity of trypsin in Spodoptera frugiperda. $\mathrm{F}=175.87 ; \mathrm{p}<0.001$.

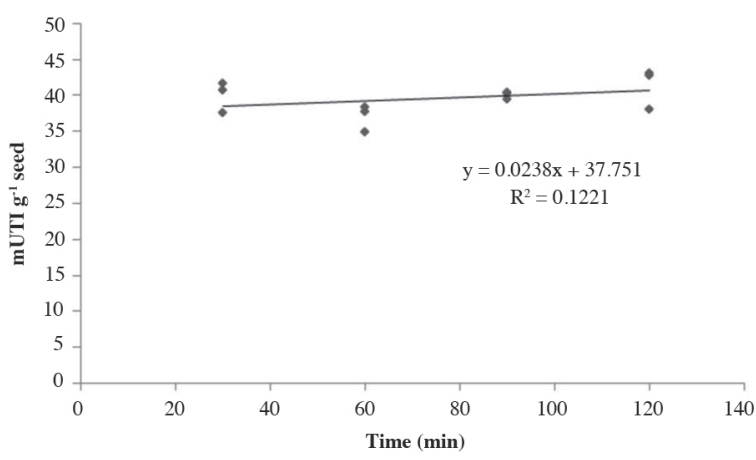

Figure 2. Curve of the effect of the extraction period of the castorbean cake inhibitor on the inhibitory activity of trypsin in Spodoptera frugiperda. $\mathrm{F}=1.5425 ; \mathrm{p}=0.2426$. 


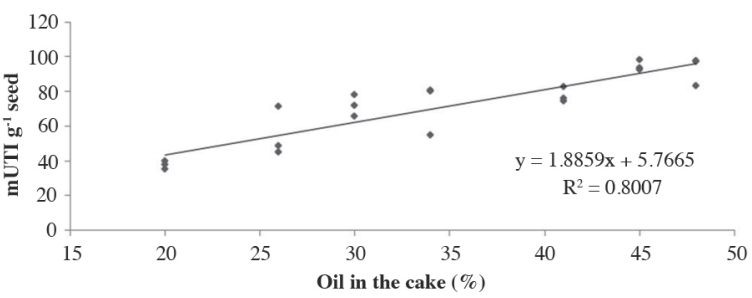

Figure 3. Curve of trypsin inhibition in vitro caused by castor-bean cake extracts with different oil contents. $F=76.33 ; p<0.001$.

the degreasing time needed to obtain castor-bean cakes because, the longer the oil extraction (therefore, lower oil content), the lower the inhibition. This fact shows that this molecule able to inhibit trypsin in S. frugiperda may be organic because, even with their affinity for polar solvents in the extraction, it also has some affinity with non-polar solvents required for degreasing, besides explaining the lack of inhibition in the extracts $\mathrm{Ac} 0 \%, \mathrm{Et} 0 \%$, and $\mathrm{Me} 0 \%$, due to the use of castor-bean cake without oil in the extraction of trypsin inhibitor.

Even with all this evidence, there is the possibility that this molecule might be a lipoprotein because of its affinity for polar and non-polar solvents; however, the fact that the inhibitory activity has remained unchanged when Rossi et al. (2010) treated the castor-bean leaf extract with $\beta$-mercaptoethanol indicates that this trypsin inhibitor is not a protein.

\section{Fractionation of Aq20\% extract by adsorption flash chromatography}

Before being subjected to chromatography, Aq20\% extract showed $795.20 \mathrm{mUTI} \mathrm{g}^{-1}$ extract. The eluents used were: ethyl acetate, ethanol, and methanol in increasing order of polarity. The extract was solubilized in distilled water at a concentration of $0.06 \mathrm{~g} \mathrm{~mL}^{-1}$ for the first chromatography. Through the enzymatic assay performed with the fractions, it was possible to observe that the inhibitor began being eluted from fraction 17 , corresponding to the interphase ethyl acetate/ethanol. The inhibitory activity for this peak was 66.80 mUTI g $^{-1}$ fraction (Figure 4).

The formation of a tail in the chromatographic curve was observed, indicating the possibility of a highly concentrated sample, and therefore a new chromatography was performed at a concentration $0.01 \mathrm{~g} \mathrm{~mL}^{-1}$ extract (Figure 5).

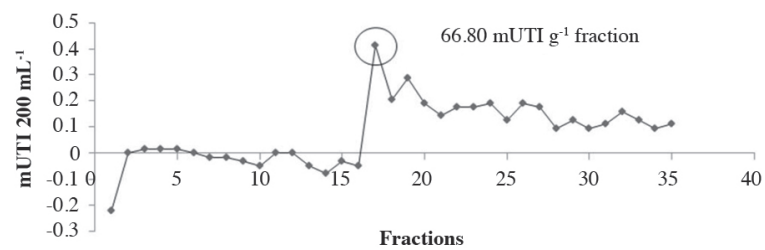

Figure 4. Chromatogram 1. Detection of the inhibitor via enzymatic assay of trypsin inhibition in Spodoptera frugiperda. Sample: 0.06 g $\mathrm{mL}^{-1}$ of distilled water. Fractions: 1-16 = Ethyl acetate; $17=$ Interphase; 18-25 = Ethanol; 26 = Interphase; and 27-35 = Methanol.
The chromatography presented in Figure 6 shows variations in the baseline, and it was possible to observe a peak in fraction 10 , with a trypsin inhibitory activity $221.81 \mathrm{mUTI} \mathrm{g}^{-1}$ fraction, corresponding to the interphase ethyl acetate/ethanol. The extract was applied to the column at a concentration of $0.5 \mathrm{~g} \mathrm{~mL}^{-1}$ water, and the inhibitor was eluted by the interphase formed between the ethyl acetate and the ethyl acetate/ethanol solution in the ratio of $70: 30(\mathrm{v} / \mathrm{v})$, corresponding to the fractions $5-11$, with a peak of trypsin inhibitory activity of 8906.12 mUTI g-1 fraction (Figure 6).

Carvalho (2009) performed a chromatographic isolation in the ethanol extract of castor-bean leaves, and the recovered fraction with the greatest inhibitory activity was eluted by the ethanolic mobile phase, with $2100 \mathrm{mUTI}^{-1}$ extract. In the present work, the activity of Aq20\% extract was 795.2 mUTI g $^{-1}$ extract before being purified, and the highest inhibitory activity was obtained at the peak corresponding to the fractions 5-11

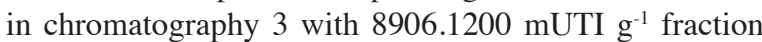
(Figure 6). This recovered inhibitory activity probably occurred due to the optimization of the mobile phase with a lower concentration of ethanol that may have eluted the trypsin inhibitor more effectively. In all the runs, it was possible to observe the presence of inhibition peaks, but it was not possible to obtain a defined peak of trypsin inhibition. It was observed that the inhibitor was eluted by a small percentage of ethanol in ethyl acetate.

\section{Effects of Aq20\% extract addition on the diet at different developmental stages of $S$. frugiperda}

It was found that caterpillars fed with the diet containing trypsin inhibitor excreted larger amounts of protein, with an average of $215.61 \pm 24.82 \mu \mathrm{mol} \mathrm{g}^{-1}$ feces $(\mathrm{F}=7.9729$;

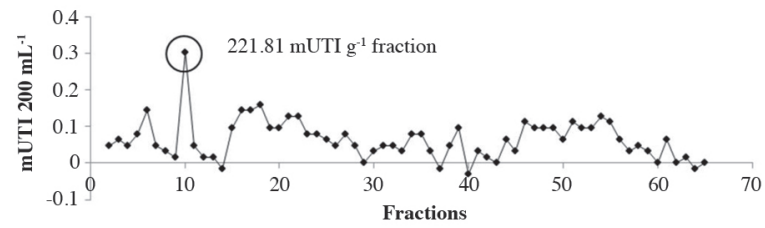

Figure 5. Chromatogram 2. Detection of the inhibitor via enzymatic assay of trypsin inhibition. Sample: $0.01 \mathrm{~g} \mathrm{~mL}^{-1}$ of distilled water. Fractions: 1-8 = Ethyl acetate; 8 = Interphase; 10-37 = Ethanol; 38 = Interphase; 39-62 = Methanol.

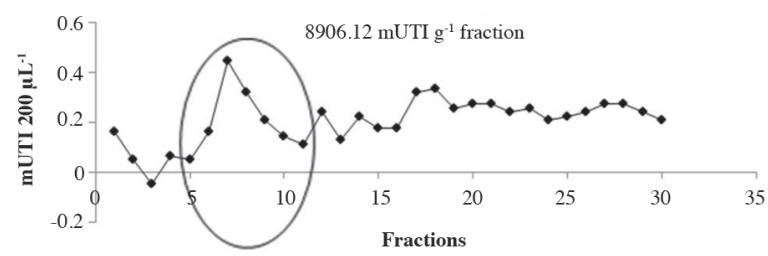

Figure 6. Chromatogram 3. Detection of the inhibitor via enzymatic assay of trypsin inhibition. Sample: $0.5 \mathrm{~g} \mathrm{~mL}^{-1}$ of distilled water. Fractions: 1-6 = Ethyl acetate; $7=$ Interphase; 8-11 = Ethyl acetate Ethanol 70:30; 12 = Interphase; 13-21 = Ethyl acetate/Ethanol 30:70; 22 = Interphase, and 23-30 = Ethanol. 
$\mathrm{p}=0.0224)$. For the other biological characteristics negative influence of trypsin inhibitor was not observed (Table 2). The adult insects from caterpillars fed with diets containing the inhibitor had their oviposition period reduced. However, the duration of larval period, duration of pupal period, pupal weight, number of eggs per couple, pre-oviposition period, longevity, and fecundity were not affected.

It is known that insects have defense mechanisms against the secondary metabolites produced by plants. When it comes to digestion inhibitors, two mechanisms are the most common: the first involves the accentuated expression of protease inhibited, seeking to increase its activity against the inhibitor whereas, in the second one, several isoenzymes are synthesized, aiming that some of them are not inhibited. Both mechanisms deviate the essential amino acids for growth to the synthesis of digestive enzymes, thus causing a shortage in the development. Therefore, it is necessary an in vivo assay, in addition to an in vitro detection of trypsin inhibition, since the plant-insect interactions are far more complex nature, and cannot be evaluated only under laboratory conditions (Paulillo et al., 2000; Brioschi et al., 2007).

The results obtained by Ramos-López et al. (2010) demonstrated negative effects on larval duration, larval and pupal survival, and pupal weight of insects treated with methanol extract of castor-bean seeds. There was an increase in larval duration, as well as pupal and larval weight and survival reduction at $1.6 \mathrm{~g} \mathrm{~L}^{-1}$; and at $9.6 \mathrm{~g} \mathrm{~L}^{-1}$ none insects survived.

Ramos-López et al. (2010) compared mean lethal concentration $\left(\mathrm{LC}_{50}\right)$ of hexane, methanol, ethyl acetate extracts of castor-beans leaves and seeds and two compounds present in castor-beans, ricinine and castor oil, both purified. The most polar extracts caused the greatest effect on the development of the fall armyworm and the authors concluded that the reduction in the development of this insect was caused by the ricinine (alkaloid) and the castor oil. The toxic effect was attributed mainly to ricinine, compound mostly found in seeds with polar characteristics and $\mathrm{LC}_{50} 0.38 \mathrm{~g} \mathrm{~L}^{-1}$ (Ferraz et al., 1999).

In the present work, the seed was degreased prior to the extraction of the inhibitor with water, and thus ricinine may have also been extracted; it implies that the same extract at $4 \mathrm{~g} \mathrm{~L}^{-1}$ in the diet was not able to cause significant changes in the development of treated insects. The sublethal effect of Aq20\% extract, added to the increase in the concentration of soluble protein in feces, could be an indicative that the inhibitor is ricinine if the other biological characteristics of development evaluated had been modified (Ferraz et al., 1999; Ramos-López et al., 2010); however, it is likely that ricinine is not present in the Aq20\% extract obtained in this study, because it did not cause negative effect on the development of $S$. frugiperda.

Yu et al. (2003) studied populations of S. frugiperda resistant 562 fold to carbaryl and 354 fold to methylparathion. When enzymes responsible for the detoxification of these populations were compared with those of caterpillars reared in laboratory, an increase in the activity of these enzymes was examined, which explains the greater resistance of these insects to the evaluated insecticides.

The lack of changes in the development of fall armyworm caused by the reduction in the absorption of amino acids is probably due to some strategy of defense and/or detoxification of this pest as the one reported by Yu et al. (2003) to carbaryl and methyl-parathion. Another probable reason is the use of Aq20\% extract, where the inhibitor concentration is low and may not have achieved the concentration required to cause some effect on the development of fall armyworm. Carvalho (2009) found that when the caterpillar of S. frugiperda were fed with a diet containing the chromatographically purified fraction of the ethanol extract from the castor-bean leaves, there was an increase in the larval period and a decrease in the pupal weight.

\section{CONCLUSIONS}

The castor-bean seeds contain compounds with antitryptic activity in $S$. frugiperda. The castor-bean cake degreased with $20 \%$ oil is the most suitable source for obtaining trypsin inhibitor by extraction with water in the ratio of 1:40 (w/v) for $30 \mathrm{~min}$.

The diet supplemented with Aq20\% extract causes

Table 2. Biological characteristics of Spodoptera frugiperda fed with a diet containing aqueous extract of castor-bean cake.

\begin{tabular}{|c|c|c|c|c|}
\hline \multirow[b]{2}{*}{ Characteristic } & \multicolumn{2}{|c|}{ Treatment } & \multirow[b]{2}{*}{$\mathrm{F}$} & \multirow[b]{2}{*}{$\mathrm{p}$} \\
\hline & Control & $4 \mathrm{~g} \mathrm{~L}^{1}$ & & \\
\hline Duration of larval period, $\mathrm{d}$ & $21.44 \pm 6.35 \mathrm{a}$ & $21.25 \pm 4.08 \mathrm{a}$ & 0.05 & 0.83 \\
\hline Protein in feces, $\mu \mathrm{mol} \mathrm{g}{ }^{-1}$ & $215.61 \pm 24.82 \mathrm{a}$ & $177.70 \pm 16.90 \mathrm{~b}$ & 7.97 & 0.02 \\
\hline Duration of pupal period, $\mathrm{d}$ & $12.73 \pm 2.43 \mathrm{a}$ & $12.66 \pm 2.38 \mathrm{a}$ & 0.03 & 0.87 \\
\hline Pupal weight, $g$ & $0.2782 \pm 0.03 \mathrm{a}$ & $0.2813 \pm 0.03 a$ & 0.29 & 0.59 \\
\hline Pre-oviposition, d & $4.64 \pm 2.29 \mathrm{a}$ & $5.00 \pm 2.55 \mathrm{a}$ & 0.11 & 0.74 \\
\hline Female longevity, $\mathrm{d}$ & $20.27 \pm 4.22 \mathrm{a}$ & $18.33 \pm 5.66 \mathrm{a}$ & 0.88 & 0.36 \\
\hline Male longevity, $\mathrm{d}$ & $18.27 \pm 4.29 \mathrm{a}$ & $15.78 \pm 6.10 \mathrm{a}$ & 1.15 & 0.30 \\
\hline Oviposition, $\mathrm{d}$ & $20.55 \pm 3.73 a$ & $15.67 \pm 4.82 \mathrm{~b}$ & 6.53 & 0.02 \\
\hline Eggs/couple & $1890.00 \pm 665.12 \mathrm{a}$ & $1691.11 \pm 721.27 \mathrm{a}$ & 0.41 & 0.53 \\
\hline
\end{tabular}

Means followed by the same letter in each line are not statistically different according to the Scott-Knott test at $5 \%$ significance level. 
an increase in the protein excretion by caterpillars of $S$. frugiperda and reduces its oviposition period. The ricinine is not the compound responsible for causing trypsin inhibition in fall armyworm.

\section{ACKNOWLEDGEMENTS}

We thank the National Council of Scientific and Technological Development (CNPq), the CAPES Foundation (Brazilian Ministry of Education) and the Minas Gerais State Foundation for Research Aid (FAPEMIG) for the financial support provided.

\section{LITERATURE CITED}

Benchabane, M., U. Schlüter, J. Vorster, M.C. Goulet, and D. Michaud. 2010. Plant cystatins. Biochimie 92:1657-1666.

Benjakul, S., W. Visessanguan, and P. Thummaratwasik. 2000. Isolation and characterization of trypsin inhibitors from some Thai legume seeds. Journal of Food Biochemistry 24:107-127.

Bradford, M.M. 1976. A rapid and sensitive method for quantitation of microgram quantities of protein utilizing the principle of protein-dye binding. Analytical Biochemistry 72:248-254.

Brioschi, D., L.D. Nadalini, M.H. Bengtson, M.C. Sogayar, D.S. Moura, and M.C. Silva-Filho. 2007. General up regulation of Spodoptera frugiperda trypsins and chymotrypsins allows its adaptation to soybean proteinase inhibitor. Insect Biochemistry and Molecular Biology 37:1283-1290.

Carlini, C.R., and M. F. Grossi-de-Sá. 2002. Plant toxic proteins with insecticidal properties. A review on their potentialities as bioinsecticides. Toxicon 40:1515-1539.

Carvalho, G.A. 2009. Extração e análises cromatográficas de um inibidor de tripsina presente em folhas de mamona e sua ação no desenvolvimento da lagarta-do-cartucho do milho. Dissertação Mestrado em Agroquímica. Universidade Federal de Lavras, Lavras, Brasil.

Erlanger, B.F., N. Kokowsky, and W. Cohen. 1961. The preparation and properties of two new chromogenic substrates of trypsin. Archives of Biochemistry and Biophysics 95:271-278.

Ferraz, A.C., M.E. Angelucci, M.L. Da Costa, I.R. Batista, B.H. De Oliveira, and C. Da Cunha. 1999. Pharmacological evaluation of ricinine, a central nervous system stimulant isolated from Ricinus communis. Pharmacology Biochemistry and Behavior 63:367375 .
Jongsma, M.A., and J. Beekwilder. 2011. Co-evolution of insect proteases and plant protease inhibitors. Current Protein \& Peptide Science 12:437-447.

Kasten Jr., P., A.A.C.M. Precetti, e J.P.P. Parra. 1978. Dados biológicos comparativos de Spodoptera frugiperda (J.E. Smith, 1797) em duas dietas artificiais e substrato natural. Revista de Agricultura 53:68-78.

Lopes, A.R., M.A. Juliano, L. Juliano, and W.R. Terra. 2004. Coevolution of insect trypsins and inhibitors. Archives of Insect Biochemistry and Physiology 55:140-152.

Mosolov, V.V., and T.A. Valueva. 2005. Proteinase inhibitors and their function in plants: A review. Applied Biochemistry and Microbiology 41:227-246.

Mosolov, V.V., and T.A. Valueva. 2008. Proteinase inhibitors in plant biotechnology: A review. Applied Biochemistry and Microbiology 44:233-240.

Paulillo, L., A.R. Lopes, P.T. Cristofoletti, J.R.P. Parra, W.R. Terra, and M.C. Silva-Filho. 2000. Changes in midgut endopeptidase activity of Spodoptera frugiperda (Lepidoptera: Noctuidae) are responsible for adaptation to soybean proteinase inhibitors. Journal of Economic Entomology 93:892-896.

R Core Team. 2012. R: A language and environment for statistical computing. R Foundation for Statistical Computing, Vienna, Austria. Available at http://www.r-project.org/ (accessed 7 December 2012).

Ramos-López, M.A., S. Pérez, G.C. Rodríguez-Hernández, P. Guevara-Fefer, and M.A. Zavala-Sánchez. 2010. Activity of Ricinus communis (Euphorbiaceae) against Spodoptera frugiperda (Lepidoptera: Noctuidae). African Journal of Biotechnology 9:1359-1365.

Rossi, G.D., C.D. dos Santos, M.G. Cardoso, A.D. Corrêa, C.M.P. de Abreu, and L.V. Paiva. 2010. Coffee leaf miner trypsin inhibition with castor bean leaf extracts mediated by a non-protein agent. Ciência e Agrotecnologia 34:361-366.

Tsybina, T.A., Y.E. Dunaevsky, A.Kh. Musolyamov, T.A. Egorov, and M.A. Belozersky. 2001. Cationic inhibitors of serine proteinases from buckwheat Seeds. Biochemistry 66:941-947.

Zhou, J.Y., H. Liao, N.H. Zhang, L. Tang, Y. Xu, and F. Chen. 2008. Identification of a Kunitz inhibitor from Albizzia kalkora and its inhibitory effect against pest midgut proteases. Biotechnology Letters 30:1495-1499.

Yu, S.J., S.N. Nguyen, and G.E. Abo-Elghar. 2003. Biochemical characteristics of insecticide resistance in the fall armyworm Spodoptera frugiperda (J.E. Smith). Pesticide Biochemistry and Physiology 77:1-11. 